\title{
Restoration of ancient bronze bells. Part II: welding
}

\author{
Restauración de campanas de bronce antiguas. Parte II: soldadura
}

Ernesto Ponce L. ${ }^{1}$

Recibido 22 de abril de 2014, aceptado 25 de julio de 2014

Received: April 22, $2014 \quad$ Accepted: July 25, 2014

\begin{abstract}
There is a big number of church bells from $16^{\text {th }}$ to $19^{\text {th }}$ centuries in the highlands of Northern Chile, which are damaged by use during centuries and by falls due to earthquakes that affect the region. Some of them are cracked or have lost some of their parts. The aim of this work was to use an efficient welding method to repair the pieces lacking some of their parts, leaving a minimum trace of repair and extending their useful life. Restoration of a bell with smelting defects, lacking some parts, is described. The first method employed was an alloy similar to that of the piece under study, which eliminated the issue of material incompatibility between the filler and the bell. In order to do this, X-ray fluorescence was used to analyze a part of the repair zone. With data obtained from analysis, smelted bars were used for welding and plates of equivalent geometry were used to replace the missing parts. The second method used was commercial silver-tin alloy welding with flux coating. In both cases, results indicated a good joint, however, in the second case cost is higher and the color results make restoration evident. Both of the alloy restorations remained in $\alpha$ phase, which is ductile and has no aging problems. Ultrasonography and penetrant liquids detected no cracks. A significant number of valuable colonial bells, now damaged and out of service, restoration is justified. They must be preserved, since they are a valuable part of the nation's cultural heritage.
\end{abstract}

Keywords: Metallurgy restoration, ancient metallurgy, bells, bell restoration, bronze welding.

\section{RESUMEN}

Una gran cantidad de campanas de los siglos XVI al XIX de iglesias del Altiplano chileno se encuentran dañadas por el uso durante siglos y caídas por los sismos que afectan la región. Algunas presentan grietas, a otras les faltan pedazos. El objetivo fue emplear un método eficiente de soldadura para restaurar aquellas piezas con trozos faltantes, dejando un mínimo rastro de la restauración y permitiendo una larga vida útil. Se muestra la reparación de una copia con defectos de fundición de una campana a la que faltaban trozos. En un primer método se empleó una aleación similar a la pieza, eliminando el problema de incompatibilidad de materiales entre el aportado para soldar y la campana. Se analizó por fluorescencia de rayos X una mиеstra de la zona a reparar, con estos datos se fundieron barras para emplear como soldadura y placas de equivalente geometría para completar las partes faltantes. El segundo método empleado fue de soldadura aleación plata-estaño, con revestimiento fundente. En ambos casos los resultados indicaron buena unión, sin embargo en el segundo, el costo fue más elevado y el color diferente acusa la restauración. En ambas restauraciones la aleación permaneció en fase $\alpha$, que es dúctil y no presenta problemas de envejecimiento. Exámenes de ultrasonidos y líquidos penetrantes no detectaron grietas. Se justifican estos trabajos por la gran cantidad de valiosas campanas del período colonial que se encuentran dañadas y fuera de servicio. Necesitan ser conservadas, porque encierran una riqueza que es patrimonio cultural de la nación.

Palabras clave: Restauración metalúrgica, metalurgia antigua, campanas, restauración de campanas, soldadura para bronce.

1 Escuela Universitaria de Ingeniería Mecánica. Universidad de Tarapacá. Casilla postal 6-D. Arica, Chile. E-mail: eponce@uta.cl 


\section{INTRODUCTION}

Conventional welding repair with electrical equipment or with a combination of gases such as oxyacetylene or oxybutane is difficult, since there is not always compatibility between the filler material and the piece material, even if they are both copper-based. In the past, a drastic fusion repair technique was used: The crack was bevelled and amplified with cutting tools; then, the contour was covered with a mix of clay and foundry sand, forming a tunnel for the circulation of molten metal. The entrance and the U-shaped discharge end of the trough were left free in order to hold the casting and allow for the canal to be completely filled. The casting was poured into the repair mold for bronze to come out from the other end. This provided time to smelt the separated walls of the fissure, which would take some seconds. Once the process was finished and cooled down, the mold was taken out, and excess casting was eliminated with appropriate tools [1]. This technique was complex and dangerous. An old Spanish proverb said: "A broken bell never heals", meaning efforts to mend the impossible was useless.

Repairing ship propellers and old or new bells using built-up welding, either with electrical equipment or gases, tends to be complex. Welding the piece may be incompatible, because of the different chemical composition of the filler materials and the base material (even if they are both copper-based) [2].

Moreover, volatilization of the tin-zinc alloy weakens the area surrounding the fusion.

The area to be welded must be first heated in order to avoid sudden cooling that can create cracks. The weld can well resist works loads, but a crack can occur in the bell, just next to the weld bead [3]. Figure 1 shows penetrating liquids, and the crack location next to the welded area.

Powder metallurgy allows for good crack repair, since narrow crack separations can be filled with this fine material. However, this method is not efficient when there is a big cavity. The flame of the torch spreads powder material in open areas. When applied on cracks, powder stays protected inside the crack, and it is not easy to remove it with the gas stream.

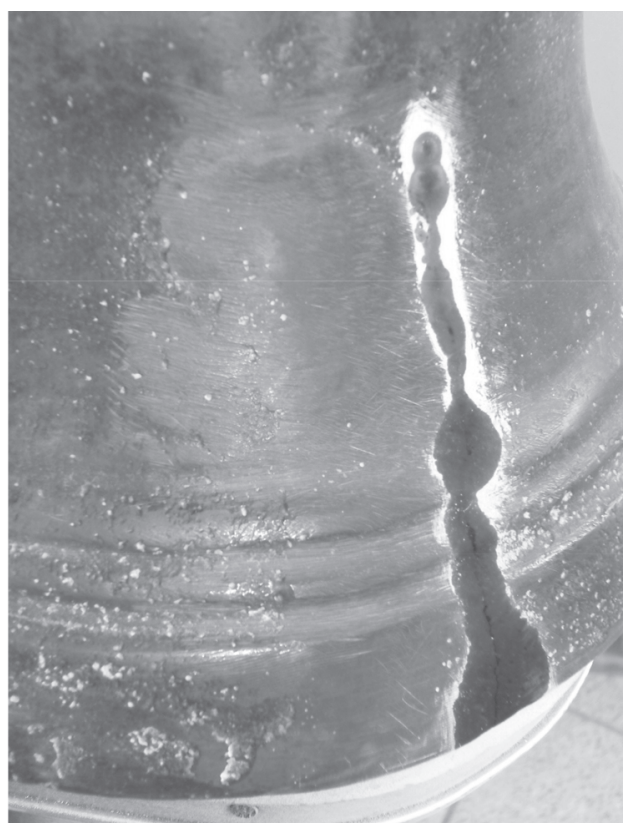

Figure 1. Crack highlighted by penetrating liquids, on the right side of the welded area.

In Europe, there are companies specialized in bell restoration with an associated high cost since the trade of the bell founder is disappearing. Some of them have inherited the art of bell founding and repair for generations.

It is worth noting that only some types of bronze can be welded. Common bronze with copper, tin, and a small percentage of zinc and lead is almost impossible to be welded. This type of bronze generates a lead layer on the surface when heated, creating a low-resistant weld. On the contrary, phosphorated bronze can be readily welded.

It is also worth noting that in order to obtain quality welded joints, the pieces must be perfectly adapted, and base metals must be clean and oxide-free. In most of the cases, it is recommended that a 0.003 to $0.08 \mathrm{~mm}$ distance be kept for better capillary action. Nevertheless, it is not uncommon to have spaces of around $0.6 \mathrm{~mm}$ in some welding operations. Cleaning of surfaces is extremely important, since contamination can produce a negative final result. The two main cleaning methods are chemical cleaning and mechanical abrasive cleaning [4].

Time and temperature effects are as well important factors to consider for good-quality welding. In 
general, the temperature of the weld selected must be above the fusion point of the filler metal. The following factors must be considered to select temperature: First, the lowest possible welding temperature must be used. Second, the effects of heating on the joint must be minimized to avoid concentrating on only one area. Third, constant flow of filler material must be ensured.

There is also a recommendation for weld adhesion: the base metal must be soluble in some of the metals forming the filler alloy. Chemical composition of the bell must be analysed in this case.

No case is similar to another and methods can vary among specialists, so bell repair is an art, not a science.

As an example of important damaged pieces, Figure 2 shows a bell tower partly destroyed by the 2005 earthquake. Figure 3 shows an old bell fallen

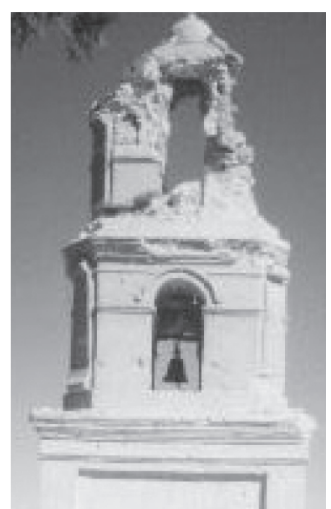

Figure 2. Bell tower in Northern Chile, damaged by an earthquake in 2005 .

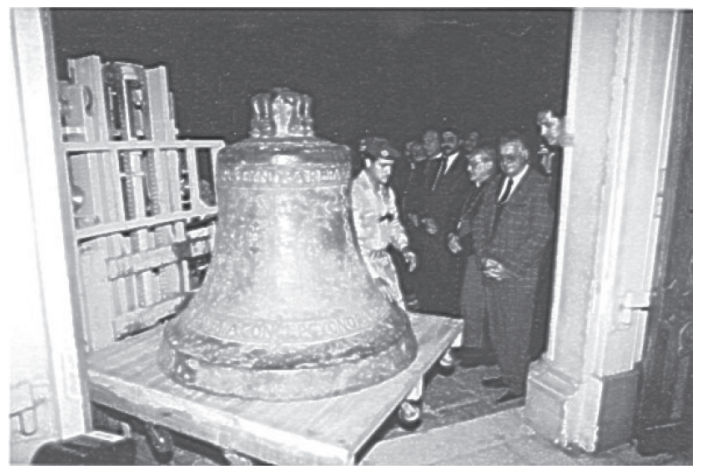

Figure 3. Bell fallen and damaged during the 1866 earthquake in Arica, Northern Chile. during the 1866 earthquake in Arica. In the upper circular perimeter is the inscription "MARTYN DE AREBALO ME FECY AÑO DE 1729", and in the lower circumference is "NRA. S. DE LA CONCEPCYON ORA PRONOBYS. LA MANDO HAZER D. PEDRO BELARDE" (Martyn of Arebalo made me, in 1729. Our Lady of Conception, pray for us. Don Pedro Belarde ordered it) [5].

\section{METHODOLOGY}

First Method. Restoration of missing areas with bronze of similar chemical composition.

The repaired bell lacked some pieces in the crown area, covering an area bigger than the crack being problematic. Given the difficulties known for some cases of propeller and bell repair by means of conventional welding and commercial filler welding, the method employed was an alloy similar to that of the piece under study, which eliminated the issue of material incompatibility between the filler and the bell. In order to do this, a sample of the repair zone was analyzed, and a sufficient amount of bronze, of the same composition as that of the original piece, was smelted in the crucible. Bars of $8 \mathrm{~mm}$ diameter and flat plates, of the same thickness as the missing parts, were cast from the crucible. The interior of the bell was filled with compacted foundry sand to prevent spilling into the weld. The plates, cut with the geometry of the cavity, were mounted in the spaces to be covered. The repair area was placed horizontally, the areas surrounding the joint were pre-heated, and welding was performed with an oxyacetylene torch.

Repaired piece. A bronze copy of a steam locomotive bell of a model similar to that of H.K. Porter \& Co's Locomotive Works (H. N. Sprague Supt.) N 1323 Pittsburgh P.A. 1891, had smelting defects in its crown with material missing in areas of this flat surface.

X-ray fluorescence analysis of a sample from the repair area showed the following percentage composition: $\mathrm{Cu} 77.10 ; \mathrm{Zn}$ 14.40; Sn 4.49; Si 1.08; $\mathrm{Pb} 0.95 ; \mathrm{Al} \mathrm{0.61;} \mathrm{Fe} \mathrm{0.56.} \mathrm{Elements} \mathrm{with} \mathrm{percentages}$ lower than $0.3 \%$ were discarded.

This alloy is in the range of UNS numbers: C31200-C38590, leaded brasses-copper zinc-lead alloys category [6]. 
Three separate crucibles were employed: One for $\mathrm{Cu}-\mathrm{Si}-\mathrm{Al}-\mathrm{Fe}$, another for $\mathrm{Zn}$ and a third one for $\mathrm{Sn}-\mathrm{Pb}$. In three small electrical ovens, a little amount was smelted, resulting in a 500g alloy similar to that of the sample. When $\mathrm{Cu}$ was molten, the contents of the other crucibles were poured into it. The mix was removed with a quartz rod to avoid volatilization of lower melting point components. The liquid alloy was poured into sand molds to produce $8 \mathrm{~mm}$ section bars (to be used as filler material). The liquid alloy was as well poured into a leveled ceramic brick surrounded by foundry sand, so as to produce a small flat sheet from which repair patches would be then trimmed off.

In order to achieve better welding adhesion, an approximately $2 \mathrm{~mm}$ thick plate of the same material was placed under the trimmed plates to be welded. Sound was not affected in this area, since it is just below the base from which the bell is held. In other cases, such as repair on a slope, a stainless steel support thin plate should be placed and removed after the joint has been carried out. Once the trimming of patches had been carried out, the bell was filled with compacted molding sand and $5 \%$ weight moisture. The area was dried to avoid steaming due to an increase of temperature. It was then welded with an oxyacetylene torch, heating the surroundings, edges and patches, before applying the filler material from the previously prepared bars. A commercial boron-based flux was used, INDURA $\mathrm{N}^{\circ} 10$. Machining was performed manually once the joint was cooled down. The cost was US $\$ 0.07 / \mathrm{g}$ of welding.

Bronze welding needs long pre-heating in the joint areas. Higher preheat temperatures may be required to counterbalance the low heat input, particularly with alloys with thick sections [5]. The temperature required can be verified by the color it takes on: It should be almost faded, dark magenta [7].

Second method. Another repair alternative chosen was to weld with a filler bar of 50\% Ag and 50\% $\mathrm{Sn}$, with flux coating. Even though it provides good flow and bronze adhesion, it leaves excess weld metal that must be removed mechanically, then using finetools for the finishes. The cost is significantly high (approximately US $\$ 0.7$ per welding gram), being unaffordable for bigger repair. Another inconvenience is the grayish white color in the joint that does not match bronze color. It is worth noting that it is not always possible to repair the bell with this technique, since sometimes the bell alloy does not allow weldability. As in the first method, the interior of the bell was filled with compacted foundry sand to prevent spilling of the weld and fall of filler patches. $2 \mathrm{~mm}$ thickness patches shaped in the form of the cavity were mounted in the bell crown. The bell was placed in its natural position and was then welded with Ag-Sn filler material and an oxyacetylene torch.

When using this method, surfaces must be moistured with weld to create a consistent base. It is recommended that a small weld puddle be maintained in order to promote homogeneous solidification. Cracking is thus minimized.

States and processes are indicated in Figures 4-7.

To compare the benefits of this method, an area was welded with $50 \% \mathrm{Ag}$-Sn filler material, and another zone was soldered with bronze similar to that of the bell. By means an ultrasound equipment, weld thickness was measured in the restored zone. Possible external cracks were sought through penetrant liquid.

Comparative Table 1 shows the following for the different filler metals:

Table 1. Method comparison.

\begin{tabular}{|c|c|c|c|}
\hline Material & Weldability & $\begin{array}{c}\text { US\$/g } \\
\text { Cost }\end{array}$ & $\begin{array}{c}\text { Defects } \\
\text { observed }\end{array}$ \\
\hline $\begin{array}{c}\text { Alloy } \\
\text { similar to } \\
\text { that of the } \\
\text { bell }\end{array}$ & Good & 0.07 & None \\
\hline $\begin{array}{c}50 \% \\
\text { Ag-Sn bar }\end{array}$ & Good & 0.71 & $\begin{array}{c}\text { Different } \\
\text { color }\end{array}$ \\
\hline
\end{tabular}

Table 2. Comparison of HB hardness in welds.

\begin{tabular}{|c|c|c|}
\hline $\begin{array}{c}\text { Material } \\
\text { resulting } \\
\text { from welding }\end{array}$ & HB & $\begin{array}{c}\text { Mechanical } \\
\text { resistance }\end{array}$ \\
\hline $\begin{array}{c}\text { With alloy } \\
\text { similar to that } \\
\text { of the bell }\end{array}$ & 97.5 & $\begin{array}{c}\text { Good } \\
\text { resistance }\end{array}$ \\
\hline $\begin{array}{c}\text { With } 50 \% \\
\text { Ag-Sn bar }\end{array}$ & 79.1 & $\begin{array}{c}\text { Less } \\
\text { resistant }\end{array}$ \\
\hline
\end{tabular}




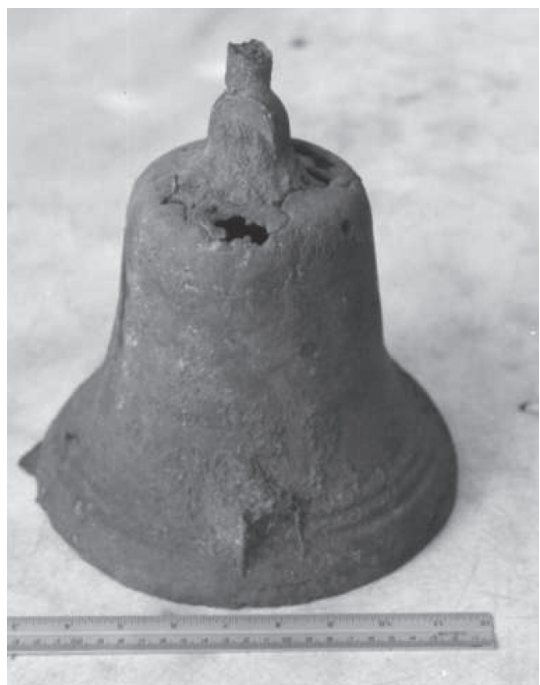

Figure 4. Bell with holes in the crown.

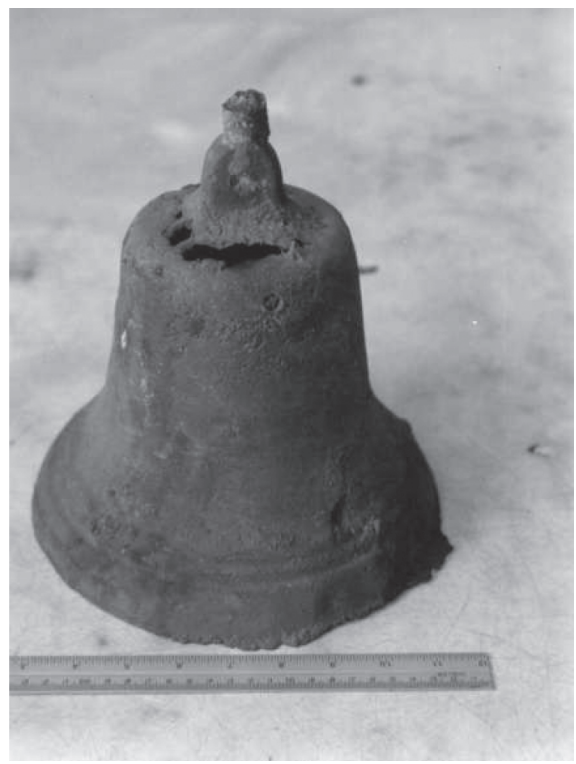

Figure 5. Opposite side of the bell.

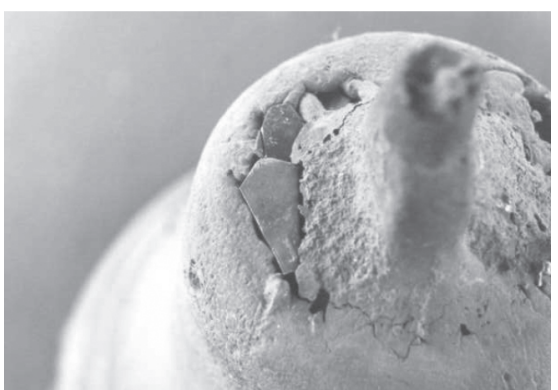

Figure 6. Installation of patches before welding.

\section{RESULTS}

Measurements from the ultrasound equipment indicated uniform thickness welding, no internal cracks or metal separations were detected. No external cracks, searched by penetrant liquids were found.

Figure 7 shows the two types of restoration by welding: The frontal side, in dark color, is bronze of the same composition as the bell. The sides and rear are whitish; Ag-Sn filler material.

Figure 8 is a $200 \mathrm{X}$ micrograph resulting from the fusion of the filler bar and the bell (bar of similar chemical characteristics as the bell metal). It can be observed that copper acts as the matrix surrounding the soft metal. By slowly lowering the lens, the first thing to stand out is the darkest metal (bronze), with some blurry white dendrites, which indicate that dendrites were more worn down during test tube polishing. A 3-second potasium dichromate attack by rub was used.

Figure 9 also shows a 200X micrograph, resulting from the bell metal fusion with $50 \%$ silver-tin filler material. The alloy matrix surrounding bronze is observed to be white, as opposed to what can be observed in Figure 8. As in the previous case, attack by rub with potassium dichromate was used for 3 seconds.

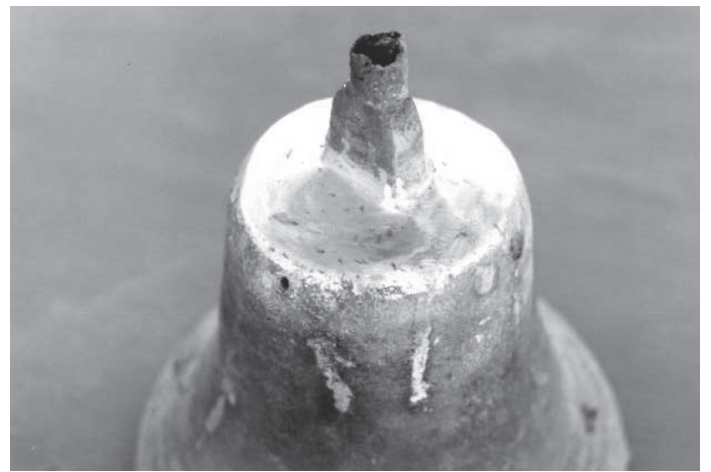

Figure 7. Restoration with bronze similar to that of the bell. The front side is dark, whereas the rear part is Ag-Sn welding. 


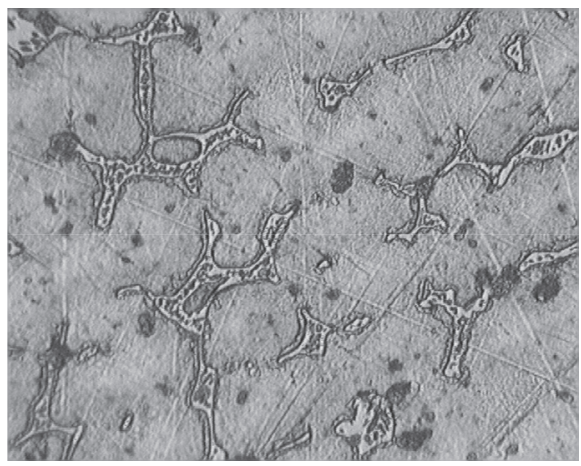

Figure 8. Welding of the same material as that of the bell. 200X.

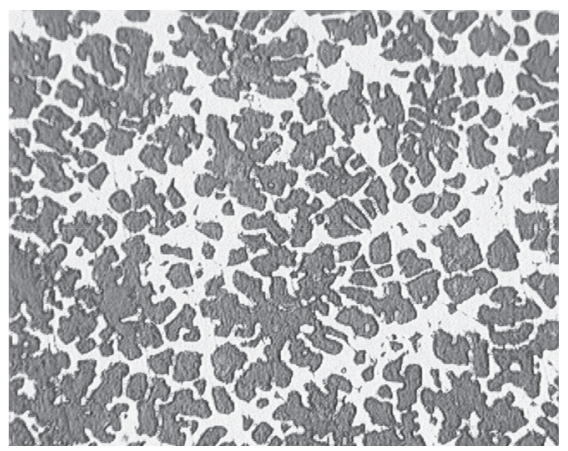

Figure 9. $50 \% \mathrm{Ag}$-Sn welding. 200X.

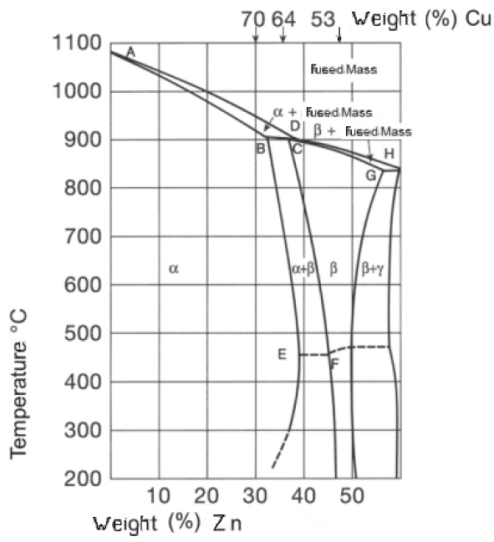

\begin{tabular}{|c|c|c|c|c|c|c|c|c|}
\hline & $\mathrm{A}$ & $\mathrm{B}$ & $\mathrm{C}$ & $\mathrm{D}$ & $\mathrm{E}$ & $\mathrm{F}$ & $\mathrm{G}$ & $\mathrm{H}$ \\
\hline Temperature ${ }^{\circ} \mathrm{C}$ & 1083 & 902 & 902 & 902 & 454 & 454 & 834 & 834 \\
\hline Zn Content \% & 0 & 32,5 & 36,8 & 37,6 & 39,0 & 45,0 & 56,5 & 60,0 \\
\hline
\end{tabular}

Figure 10. Phase diagram of the binary system $\mathrm{Cu}-\mathrm{Zn}$ [8-9].

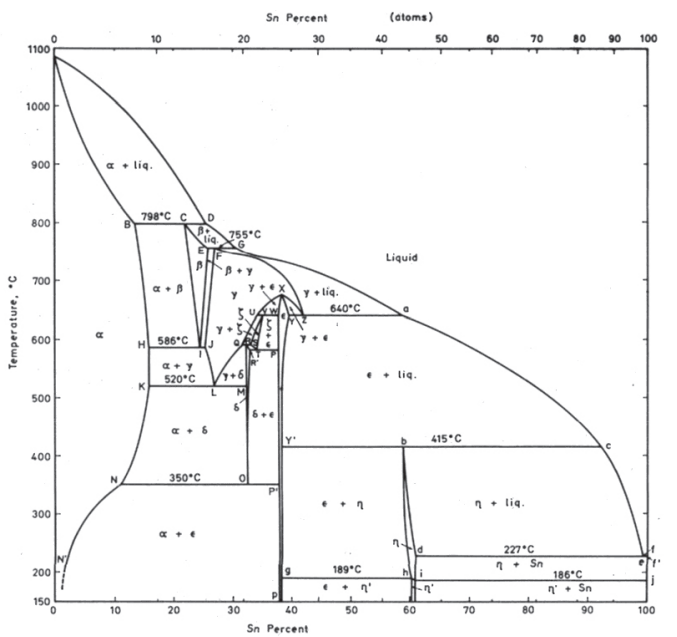

Figure 11. Phase diagram of the binary system $\mathrm{Cu}-\mathrm{Sn}[8,10-12]$.

\section{CONCLUSIONS}

In both methods, results showed good joint, which had to be machined in order to obtain a properly finished surface.

Using welding of an alloy similar to that of the bell produced better results in terms of texture, color, resistance, and cost. These are the reasons why this method is recommended. Although leaded brasses are considered not weldable, it could be soldered satisfactorily; also Oxifuel Gas Welding (OGW) is $\mathrm{NR}$, not recommended for range of C31200-C38590 UNS numbers. However, soldering is categorized as $\mathrm{G}=\operatorname{good}[6]$. In our bell the experience showed that it could be welded without problem.

"A copper-zinc alloy composed solely of $\alpha$ phase crystals (Figure 10 left) may become deformed rather cold, but is problematic for machining (this is not the case analyzed). Only the copper-zinc alloys with more than $54 \%$ of copper weight are technically significant. Therefore, only a copper-rich part of the $\mathrm{Cu}-\mathrm{Zn}$ phase diagram is described in the figure. Above the $\mathrm{ADH}$ line in the region of complete dissolution, the mixture of the two components, the copper and zinc molten predominates. On the left side of the diagram, up to $67 \%$ of copper, the domain of $\alpha$ phase predominates. To the right are the regions corresponding to phases $(\alpha+\beta)$ and $\beta$ " [8-9], which may occur by rapid cooling. In our study we have $\alpha$-phase only, given that the welding 
was slowly cooled and the alloy used has $77.1 \%$ $\mathrm{Cu}$ and $14.4 \% \mathrm{Zn}$. The alpha phase is ductile; thus, there would be no danger of brittle crack generation, which is the case of the beta phase when sudden cooling occurs.

In the copper-tin phase diagram, there is a $4.49 \%$ Sn. The phase diagram of Figure 11 (left lower side) corresponds to the $\alpha+\varepsilon$ phase, which would also be ductile.

Analyzing Figure 8, three phases appear: Tin copper crystals the 1st, 2nd zinc-copper crystals and 3rd a possible eutectic tin-lead, with a coating possibly lead (as indicated in the literature [6]).

Using silver-tin welding, the 50\% Ag and 50\% Sn commercial method is 10 times more expensive than the previous method (given the current cost of silver). Its color is different from that of the bell bronze; from an aesthetical point of view, the restored piece will not look as the original. No restoration is good because having a different color and brightness, Table 1 and Figure 7. From Table 2, HB hardness, it is seen that the resistance is lower than the brass solder, while being both ductile materials the tensile stress is about proportional to the HB hardness.

Two phases formed by liquid-liquid alloys appear when analyzing Figure 9. Bronze solidified first, which appears then embedded in a silver and tin matrix. Temperatures near $3000{ }^{\circ} \mathrm{C}$ may have volatilized part of the tin. There are no impurities. Bronze grains appear separate but are equidistant. There was a primary formation with a copper dendrite tendency. Finally, the silver-tin matrix penetrates the alloy eliminating the dendrites.

For this $14.4 \% \mathrm{Zn}$ model, the method was good. For those bells that are over $30 \% \mathrm{Zn}$ methodology should be reviewed, because over this percentage $\alpha+\beta$ phase appears (may have lower ductility and aging, Figure 10). Oxyacetylene is advisable to change the system by TIG and Argon (tungsten inert gas) because it generates lower temperatures avoiding losses of Sn and $\mathrm{Zn}$ [6].

After nearly a decade of restoration, there are not cracks generated by aging. The bell remained outdoors. Their sound remains his dominant note.
In the copper-zinc phase diagram, the right of the ABE line corresponds to precipitates (Figure 10). Aging in this area is apparent, but the line is far from being $14.4 \%$ zinc, which is the $\alpha$ phase. In the $\alpha$ phase there is no aging. This is the case of our bell and its restoration.

Comparison with published work. Information has been sought on restoration of bronze bells by welding, in the 3rd [13] and 4th Latin American Congress on Conservation and Restoration of Metals [14]. No information appears, neither in [15]. Although the method is not new, there was no where to compare similar jobs and nothing like it has been recently published.

Restoration of these old pieces is fully justified, since it allows continuing local traditions and ceremonies, which are an invaluable part of the national cultural heritage. These results make it possible to preserve ancient pieces.

\section{ACKNOWLEDGEMENTS}

The author thanks Universidad de Tarapacá (Convenio de Desempeño Internalización UTA, D. Viera, 1999) and engineer Mr. Modesto Mollo, who contributed to this work.

\section{REFERENCES}

[1] Espasa. "Enciclopedia Universal". Campanas, Espasa Calpe. Madrid, España. 1958.

[2] M. Groover. "Fundamentals of Modern Manufacturing: Materials Processes and Systems". 2nd edition. John Wiley \& Sons. 2007. ISBN: 978-81-265-1266-9.

[3] M. Schwartz. "Brazing. ASM International". 1987. ISBN: 978-0-87170-246-3.

[4] S. Brailovsky. "Soldadura en general, blanda, fuerte y autógena". Albatros. Buenos Aires, Argentina. 1962.

[5] E. Ponce, G. Foccaci y E. Quintana. "Campana fabricada en 1729 destinada a la ciudad de San Marcos de Arica". Revista Límite, $\mathrm{N}^{\circ} 2$, pp. 28-35. 1995. ISSN: 07117-2338.

[6] CDA. Copper Development Association. "Welding Copper and Copper Alloys". American Welding Society. International Standard Book Number 0-87171-505-8. 
1997. Date of visit: June 23, 2014. URL: www.copper.org

[7] Handbook-Braze Welding - ESAB. "Welding \& Cutting Products". Date of visit: June 24, 2014. URL: www.esabna.com

[8] CIMSA. "Cupropedia Bronces. Latones". Date of visit: June 24, 2014. URL: http:// www.cimsaww.com/

[9] P. Subramanian, T. Massalsky and D. Laughlin. "Thermodynamic Aspects of Massive Transformations in the $\mathrm{Cu}-\mathrm{Ga}$ and Cu-Zn Systems". Acta Metall. Vol. 36, Issue 4, pp. 937-943. 1998.

[10] J. Aguilar. "Cobre y sus Aleaciones". Date of visit: June 23, 2014. URL: http://biblio3.url. edu.gt/Libros/2013/cmI/12-Cobre_aleaciones. pdf

[11] W. Smith and J. Hashemi. "Fundamentos de la Ciencia e Ingenieria de los Materiales". 4ta Edición. Materiales Industriales I. Capítulo 6 Aleaciones no Ferrosas. McGraw Hill, México. 2004. Date of visit: June 23,
2014. URL: http://materias.fi.uba.ar/7201/ AleacionesNoferrosas.pdf

[12] J. Kitl and A. Leyt. "Transformaciones en Aleaciones Beta en el Sistema Cobre-Estaño". Informe $\mathrm{N}^{\circ}$ 63. Comisión Nacional de Energía Atómica. Buenos Aires, Argentina. 1963.

[13] ICCROM 2009.3er Congreso Latinoamericano de Restauración de Metales. Fecha de consulta: 24 de junio de 2014. URL: http:// www.iccrom.org/

[14] ICOM-CC 2011.IV Congreso Latinoamericano de Conservación y Restauración de Metales. Fecha de consulta: 24 de junio de 2014. URL: http://ipce.mcu.es/difusion/publicaciones/ monografias.html

[15] S. Díaz Martínez y E. García Alonso. "Técnicas Metodológicas aplicadas a La Conservación-Restauración del Patrimonio Metálico". Ministerio de Cultura. España. 2011. Fecha de consulta: 24 de junio de 2014. URL: http://www.calameo.com/ $\mathrm{read} / 000075335 \mathrm{c} 184 \mathrm{bd} 7 \mathrm{c} 7 \mathrm{~b} 68$ 